\title{
O mito do imperialismo paulista revisitado *
}

\author{
Fábio Lucas Pimentel de Oliveira ${ }^{* *}$
}

\begin{abstract}
Resumo
A ampla e densa agenda de pesquisa elaborada por Wilson Cano permitiu-lhe estabelecer estreito diálogo com pesquisadores, professores, especialistas, políticos e outros interessados nos problemas que perpassavam a questão regional no Brasil. A contribuição dele foi decisiva, por exemplo, na investigação da tese do imperialismo paulista, que vocalizava uma reação regionalista, em particular nordestina, às contradições provocadas pela insuficiência dinâmica das economias regionais, quando cotejadas à economia de São Paulo. Empregando o método histórico-estrutural e outros traços distintivos próprios aos estudos de Wilson Cano, objetiva-se ilustrar como ele colaborou para a explanação do falso problema que revestiu a referida tese. Argumenta-se que esse enquadramento analítico é um legado segundo o qual se torna possível elucidar aspectos que emergiram da evolução das interdependências que vinculam as regiões brasileiras antes e após 1980, envolvendo, em particular, o Nordeste e São Paulo.
\end{abstract}

Palavras-chave: Cano, Wilson, 1937-2020, Questão regional, Desenvolvimento, Imperialismo paulista.

\begin{abstract}
The myth of São Paulo's imperialism revisited

Wilson Cano's broad and dense research agenda enabled him to establish a close dialogue with researchers, professors, specialists, politicians, and others interested in the problems that pervaded the regional issue in Brazil. His contribution was decisive in the investigation of a regionalist reaction to the contradictions caused by the dynamic insufficiency of regional economies when compared to that of São Paulo, considered to be imperialist. Using the historical-structural method and other central characteristics that appear in Wilson Cano's studies, this paper illustrates how he contributed to the elucidation of the false problem that influenced this thesis. It argues that this analytical framework is a legacy according to which it is possible to explain aspects that emerged from the evolution of the interdependencies that link Brazilian regions before and after 1980, involving, particularly, the Northeast and São Paulo.
\end{abstract}

Keywords: Cano, Wilson, 1937-2020, Regional problem, Development, São Paulo’s imperialism. JEL O01, O02, N96.

\section{Introdução}

A ampla e densa agenda de pesquisa de Wilson Cano permitiu-lhe - e àqueles a quem formou e/ou influenciou - elaborar estudos, pautar cursos de graduação e pós-graduação e, sobretudo, reverter diagnósticos em instrumentos para a ação pública. Ele estabeleceu, nessa trajetória, estreito diálogo com pesquisadores, professores, especialistas, técnicos governamentais e autoridades políticas cuja atuação perpassava a Questão Regional brasileira. Em entrevista concedida ao Centro Internacional Celso Furtado (CICF), ele afirma ter-se vinculado ao tema nos anos de 1970, dadas as necessidades objetivas da recém-criada Escola de Economia da Universidade Estadual de Campinas, mas também para fazer frente, à época, aos descaminhos trilhados pelo debate regional no Brasil.

\footnotetext{
* Artigo recebido em 25 de março de 2021 e aprovado em 12 de junho de 2021.

${ }^{* *}$ Professor do Instituto de Pesquisa e Planejamento Urbano e Regional da Universidade Federal do Rio de Janeiro (IPPUR-UFRJ), Rio de Janeiro, RJ, Brasil. E-mail: fabio.oliveira@ippur.ufrj.br. ORCID: https://orcid.org/0000-0002-6210-7394.
} 
Por causa dos cursos regionais da Cepal e de um curso que dei no Rio de Janeiro, na então Universidade do Estado da Guanabara, acabei me metendo com essa temática (...) Entendi que havia questões mal colocadas e que deviam ser submetidas a uma investigação. Por exemplo, a equivocada tese do imperialismo paulista, que se baseava na ideia de que a desgraça do Nordeste era a felicidade de São Paulo (CICF, 2013, p. 296, grifos meus).

É justamente sobre a tese do imperialismo paulista, alegada por elites regionais para justificar o quadro de atraso relativo ao avanço de São Paulo durante o processo de industrialização brasileira a partir da década de 1930, que este artigo versará. No caso do Nordeste, trata-se, a tese, de uma reação regionalista às contradições provocadas pela insuficiência dinâmica da economia (Perruci, 1984) e pela crescente fraqueza política de seus representantes, herdeiros de uma formação (Furtado, 1977) hegemonizada pelo decadente binômio entre coronelismo (Vilaça; Albuquerque, 1978) e açucarocracia (Mello, 1997). Tinha como pauta um conjunto de reivindicações defensivas apresentadas ao bloco no poder nacional, o qual, por sua vez, era cada vez mais alinhado às forças que conduziam a industrialização e a integração econômica do país (Oliveira, 2008).

Objetiva-se, doravante, ilustrar como se deu a contribuição de Wilson Cano à elucidação do falso problema que revestiu a tese do imperialismo paulista. Mas não só: acredita-se, ademais, que o resgate do enquadramento analítico por ele realizado permite elucidar - sem, entretanto, exaurir aspectos que emergiram da evolução das interdependências que vinculam as regiões brasileiras após 1980, em particular entre o Nordeste e São Paulo. Alerte-se, desde já, que não se pretende convalidar o "mito" na contemporaneidade, mas tão somente averiguar, empregando as ferramentas com as quais a tese foi refutada, traços hodiernos da questão regional.

Para dar conta de tais propósitos e atestar a viabilidade dessa proposição, dividiu-se o documento em quatro seções, além desta Introdução, das Conclusões e das Referências. Na seção 1, identificam-se quatro traços distintivos marcantes da agenda de pesquisa de Wilson Cano a respeito da Questão Regional no Brasil: o pragmatismo da pesquisa aplicada, a fluidez multiescalar, o esteio do método histórico-estrutural e as considerações sobre o papel do Estado.

A seção 2 pormenoriza a maneira pela qual Wilson Cano impugnou a tese do imperialismo paulista, segundo a qual as relações entre o Nordeste e São Paulo eram nocivas em virtude do vazamento de recursos monetários, canalizados para São Paulo; da apropriação paulista de superávits regionais de comércio internacional; das sistemáticas transferências líquidas de renda para fora daquela região; e da apropriação de excedentes nordestinos por capitais situados na economia dominante do país.

A seção 3 faz uma releitura dos condicionantes da estrutura e evolução recente das economias regionais do Brasil. Nela, colocam-se os aspectos mais substantivos da dinâmica subnacional no país após 1980, tidos como preâmbulo necessário à atualização do conjunto argumentativo contrário ao mito. A seção 4 faz uso dos quatro traços distintivos da obra de Wilson Cano e, beneficiando-se do quadro de objeções ao imperialismo paulista, aponta como o aparato metodológico que o permitiu refutar essa tese possibilita, também, realizar uma renovação da leitura das interdependências que definiram as transformações estruturais e a dinâmica econômica contemporâneas da Questão Regional brasileira, com especial atenção ao caso do Nordeste. 
O mito do imperialismo paulista revisitado

\section{Traços distintivos da agenda de pesquisas de Wilson Cano}

O primeiro dos traços distintivos das análises de Wilson Cano é a natureza mais pragmática do que teórica dos seus trabalhos, transparecida tanto nos estudos sobre o subdesenvolvimento latinoamericano e brasileiro, como no exame da questão regional. Isso era uma decorrência do propósito primaz que era o de suprir a carência de um saber alternativo ao mainstream e que fosse capaz de conduzir a ação política a estratégias efetivas de desenvolvimento ${ }^{1}$. Tributário de elementos teóricometodológicos e conceituais elaborados por autores clássicos da economia política e do estruturalismo latino-americano (Fiori, 2018), ele contribuiu ativamente para o enraizamento, pelas regiões brasileiras, do pensamento da Unicamp (Brandão et al., 2020).

O segundo traço é a proficiência multiescalar, aptidão com a qual transitou entre as determinações estruturais e dinâmicas do capitalismo à escala mundial para, mediante considerações sobre o padrão de inserção internacional da América Latina na divisão internacional do trabalho, situar a particularidade do capitalismo periférico à escala nacional (Cano, 2000) e, nela, operar distinções subnacionais. Precursor, ele materializou um avanço concreto e aplicado do enfoque do desenvolvimento desigual e combinado (Smith, 1988), em especial nos estudos da concentração/desconcentração produtiva (Cano, 2007; Cano, 2008) à luz do processo de industrialização que estava em curso no Brasil (Tavares, 1998).

A opção pelo método histórico-estrutural para examinar a realidade do subdesenvolvimento, acorde à originalidade do pensamento da Cepal (Rodríguez, 2006), instituição em que trabalhou, é o terceiro daqueles traços. A multiescalaridade, associada a esse método e amparada em robusto material empírico, permitiu a Wilson Cano não só precisar uma periodização da Questão Regional no Brasil, mas problematizar interdependências dinâmicas emanadas de fluxos econômicos e demográficos sobre estruturas espaciais. Ele não nega, portanto, a existência de especificidades subnacionais Brasil afora, mas alerta que é preciso examiná-las construindo os elos e articulações escalares necessários ao correto dimensionamento dos limites e possibilidades da ação local (Brandão, 2007).

O quarto traço central da obra de Wilson Cano é reservado ao papel do Estado. A combinação entre a filiação teórico-metodológica cepalina e a percepção aguçada de uma realidade que se desejava transformar habilitou-o a evitar a insídia demiúrgica favorável a qualquer política pública, em virtude, inclusive, da existência de formas capitalistas híbridas próprias do subdesenvolvimento (Cano, 2011a). Wilson Cano jamais tomou o Estado e o planejamento como panaceias. Isso é demonstrado, especialmente, no tratamento da questão regional brasileira: a leitura feita por ele a respeito da influência teórica, constitutiva e operativa da Superintendência do Desenvolvimento do Nordeste (Sudene) é exemplar, a contar da crítica que realizou a respeito da Sudene "democrática" (1959-1964), criada e gerida por Celso Furtado em base a um diagnóstico impreciso para o contexto histórico da época (Cano, 2002).

(1) "Entendíamos que deveríamos fazer um ajuste de contas com a história econômica do país, rever essa história sob vários pontos de vista, aprofundar os estudos de política econômica e de desenvolvimento econômico e, principalmente, conhecer a realidade brasileira" (CICF, 2013, p. 295). 
Tanto é assim que, depois do Golpe Militar, em vez de celebrar a reverberação de políticas regionais inspiradas na Sudene por todo o país, Cano optou, como sempre, pelo caminho da crítica. Dessa maneira, revelou como o "modelo" de política regional brasileira houvera sido capturado por interesses capazes de omitir, na intervenção do Estado, valores e ideologias contrárias ao próprio conceito de desenvolvimento (Paula, 2016; Furtado, 2004). A instrumentação de tais políticas pelas elites e classes dominantes esterilizava a promoção de transformações socioeconômicas, perpetuando, entre e intra regiões brasileiras, o quadro herdado de heterogeneidades estruturais típicas dos países latino-americanos (Pinto, 1970) e fazia do planejamento do desenvolvimento regional um problema, antes de tudo, político (Carvalho, 2014).

A partir dos anos de 1990, esse mesmo Estado, capturado pelo viés neoliberalizante, impôs medidas mais restritivas à ação regional, constrangido pela camisa de força macroeconômica. Em termos de política, embutiram-se, desde então, estratégias seletivas, setoriais e, quando muito, infraestruturais à intervenção pública, articuladas com interesses internacionais e claramente submissas aos ditames globalizantes (Cano, 2017). Por isso, colocava-se, no horizonte, uma tendência de fragmentação da coerência inter-regional erigida ao longo dos anos de industrialização da economia brasileira (Pacheco, 1998).

Em termos federativos, encontrava-se o país em plena guerra fiscal (Cardozo, 2010) e, à luz da mundialização de capitais, as cadeias globais de valor promoviam relevante reestruturação operacional pós-fordista dos negócios (Gereffi, 2005). Em um contexto de irrefreada financeirização da riqueza (Braga, 1993), a economia brasileira viveu o aprofundamento de um processo de desindustrialização com implicações significativas à escala subnacional (Cano, 2014), ao que se soma o fato de o dinamismo produtivo do país estar assentado, nos últimos anos, nas exportações de produtos primários e/ou de baixo valor agregado.

A linha de pesquisas de Wilson Cano permitiu-lhe, portanto, evitar armadilhas e atalhos teórico-conceituais em cima dos quais foram arrazoados ações e aparatos desprovidos de necessárias mediações. A teoria dos polos de F. Perroux e o referencial centro-periferia da Cepal, empregado no diagnóstico do Grupo de Trabalho para o Desenvolvimento do Nordeste (GTDN), são os maiores exemplos disso. Assim, ele ajudou a explicar o porquê de políticas regionais desenhadas com determinadas intenções, como a da Sudene, terem logrado resultados diferentes daqueles que objetivavam (Araújo, 1982).

Permite também relativizar o próprio resgate da questão regional por parte do Governo Federal, como foi o caso, após 2003, da Política Nacional de Desenvolvimento Regional (PNDR), que seria - como tem sido - inócua diante das inescapáveis restrições fiscais e de financiamento a que está submetida, o que transparece na falta de articulação institucional e na não-centralidade em termos de agenda governamental. Não surpreende que outras ações públicas e privadas, em que a dimensão espacial é, tão somente, implícita, sejam mais determinantes para que se interprete, adequadamente, as dinâmicas que ocorrem pelo país, requerendo, com isso, um reexame acerca da efetividade da PNDR (Macedo; Porto, 2018). 
O mito do imperialismo paulista revisitado

\section{A impugnação do mito do imperialismo paulista}

Uma das situações produzidas pelo desacoplamento entre prática política e pensamento é a polêmica em torno ao "mito do imperialismo paulista sanguessuga" (Cano, 2007). Apesar dos resultados concretos alcançados pela política de incentivos fiscais da Sudene, era vigente, no Nordeste, a percepção de que o avanço de São Paulo se deu e se dava às custas do malogro nordestino. Havia, para Wilson Cano, um problema de insuficiência analítica que baseava o "mito". Ao enfrentálo, ele angariou antipatias regionalistas, mas também logrou constituir um arcabouço interpretativo segundo o qual seria possível desvelar aspectos concretos da divisão inter-regional do trabalho em um país que se industrializava (Araújo, 1979; Oliveira; Reichstul, 1973).

Liderado por São Paulo, cujas características produtivas seriam de impossível reprodução em outras partes do país (Cano, 1975), o processo de integração do mercado brasileiro proporcionou verdadeira reacomodação de estruturas econômicas e empresariais no resto do Brasil (Cano, 2007). O mito do imperialismo paulista condensava reclames quanto aos mecanismos dessa reacomodação, que haviam agravado o hiato das condições socioeconômicas do Nordeste em relação ao Sudeste.

Ante as supostas injustiças provocadas pela concentração de riquezas nesta última região, mormente após a década de 1920, a bancada política e a classe empresarial nordestinas denunciavam a inércia do Estado em face aos privilégios concedidos ao Centro-Sul (Cano, 2002). A tese arvoravase em quatro denúncias:

O de que houve e há vazão de recursos monetários líquidos pelo sistema bancário; o de que a periferia gera divisas que alimentam as importações de São Paulo; o de que, por meio de diferenciais de taxas de câmbio, de tarifas e de preços, há uma transferência de renda da periferia para São Paulo; e o de que São Paulo cresceu, pelo menos em parte, à custa do excedente periférico (Cano, 2007, p. 31)

Antes de avançar em cada um desses pontos, convém lembrar que Cano (2007) começa a desbaratar o mito pela dimensão da temporalidade. Ele relembra que os determinantes da concentração produtiva sequer remetem ao século XX, quando, de fato, ela foi agravada de 1920 até a década de 1970 e fez ressaltar as diferenças socioeconômicas regionais no Brasil, mas aos distintos processos da formação socioeconômica regional brasileira, que legaram condições diferenciadas de preservação de estruturas de poder pelo país.

Cano (2002) argumenta, em linha com Tavares (1999), que a itinerância histórico-espacial da questão fundiária e a aversão das elites regionais a se engajar em processos de acumulação que não os predominantemente mercantis - prenhes de condutas defensivas, patrimonialistas e rentistas, apartados, pois, do caráter ampliado da reprodução capitalista - foram (e têm sido) o elemento básico a considerar para compreender o porquê de existirem dinâmicas diferenciadas pelo Brasil. Assim, ele alinhou a tese do mito às narrativas e aos discursos de natureza político-institucional que buscavam perpetuar estruturas de poder voltadas a atrasar ou deter processos planejados de desenvolvimento (Dunham, 1976; Friedmann, 1967).

Cada um dos quatro argumentos mitológicos é contraposto mediante o emprego de dados estatísticos oficiais e densa pesquisa historiográfica. Eles podem ser assim sumarizados: 
- Recebimento líquido, pela economia de São Paulo, de fluxos financeiros oriundos da periferia nacional. Baseando-se nas estatísticas de movimento bancário, Cano (2007) indica que a relação empréstimos/depósitos, na periferia brasileira, era mais alta do que as verificadas em São Paulo, mesmo sendo este estado o lócus de mais de $50 \%$ da produção manufatureira nacional. Além disso, ele relembra o fato de que, até meados da década de 1950, a estrutura bancária vigente no país era do tipo comercial. Juntos, esses elementos negam a ideia de que o capital financeiro paulista estaria se capitalizando com ganhos obtidos no resto do Brasil;

- O saldo positivo da balança de comércio internacional do Nordeste financia o déficit comercial externo da economia de São Paulo. Cano (2007) demonstra que na primeira metade do século XX o saldo de comércio internacional paulista houvera sido superavitário. Com o aprofundamento da concentração industrial no estado entre 1955 e 1970, começou-se a registrar, em alguns anos, déficit externo em virtude de importações de máquinas e equipamentos sem cobertura cambial, mas em proporções bastante superiores aos superávits da periferia nacional. Tal compensação, caso existisse, teria que se dar pelo comércio inter-regional. Neste caso, Cano (2007) aponta que era a Guanabara, cuja economia já então era decadente, que se beneficiava do superávit periférico para sustentar um déficit comercial externo desassociado de qualquer sentido industrializante;

- Por meio de diferenciais de taxas de câmbio, de tarifas e de preços, há uma transferência de renda da periferia para São Paulo. Cano (2007) desdobra esse argumento em três partes, quais sejam:

oAs remessas de renda se deviam a diferenciais de produtividade entre as regiões, potencializados pela existência de uma taxa única de câmbio para todo o país. Cano (2007) rememora que eventuais taxas diferenciadas de câmbio teriam o efeito de encarecer a produção menos eficiente, no caso, a periférica, estimulando a importação de bens similares. Além disso, em se tratando de produtos primários, seus preços eram definidos no mercado internacional, não havendo, portanto, capacidade regional de alteração dos mesmos;

oA periferia não-industrializada paga altos preços pelos produtos industriais fabricados no Centro-Sul, protegidos por altas tarifas de importação. A arguição de Cano (2007) aponta que as tarifas de importação incidiam sobre todos os consumidores nacionais e, caso viessem a ser zeradas, implicariam em impactos comprometedores sobre o parque produtivo nacional, inclusive periférico, haja vista as precárias condições existentes de competitividade empresarial e sistêmica no país;

$\circ$ A política cambial favorecia a região mais industrializada. Havendo sido congelada em patamar prejudicial às exportações, entre 1947 e 1953, a taxa de câmbio não restituiu as perdas desse período mesmo quando operou em sistema de taxas múltiplas até 1957 e/ou funcionou mais livremente até 1961. No entanto, Cano (2007) sustenta que esses efeitos incidiam sobre todos os exportadores do Brasil, e não apenas os da periferia, de modo que o câmbio não era mais determinante do que os diferenciais regionais de produtividade. Ademais, mecanismos como o saldo da conta de ágios e bonificações financiavam, por meio do Banco do Brasil, o crédito agrícola que chegava de forma expressiva à periferia nacional (e, não raro, era aplicado improdutivamente). Além disso, a sistemática transferência federal de fundos públicos, que para o Nordeste correspondeu em 
média a 4\% do PIB regional, serviu tanto para reequilibrar as contas internas e internacionais de comércio, como para estimular a demanda local de bens e serviços;

- $O$ crescimento de São Paulo, ao menos em parte, deu-se à custa do excedente periférico. Trata-se de uma afirmação que evidencia o emprego do referencial centro-periferia para indicar que a economia dominante assentou parcialmente as bases "primitivas" da acumulação na exploração das economias dominadas em âmbito nacional ${ }^{2}$. Cano (1977), ao remeter às raízes da concentração industrial em São Paulo, já havia evidenciado que o desenvolvimento pioneiro de relações capitalistas de produção e de um mercado com amplitude cada vez maior lastrearam o impulso econômico paulista. Com isso, instituíram-se elos intersetoriais que facultaram o avanço da produção de bens-salário, durante os anos de 1920, para os bens de produção, indústria consolidada na década de 1950.

Foram vários os debates suscitados pela refutação que Wilson Cano fez da tese do imperialismo paulista, seja na academia, seja em instâncias políticas. No Nordeste, a repercussão das discussões, no início da década de 1980, pode ser demonstrada pelo significativo número de reportagens publicadas em um dos jornais de maior circulação do estado de Pernambuco. Em geral, elas veiculavam o teor das argumentações contrárias à ideia de que o progresso paulista se dava às custas da falência do Nordeste (Figura 1).

Figura 1

Matérias sobre o imperialismo paulista em edições impressas do jornal Diario de Pernambuco, 1981-1982

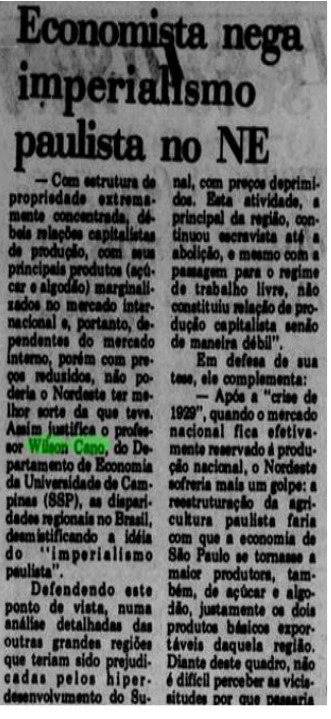

Ed. $11 / 8 / 1981$

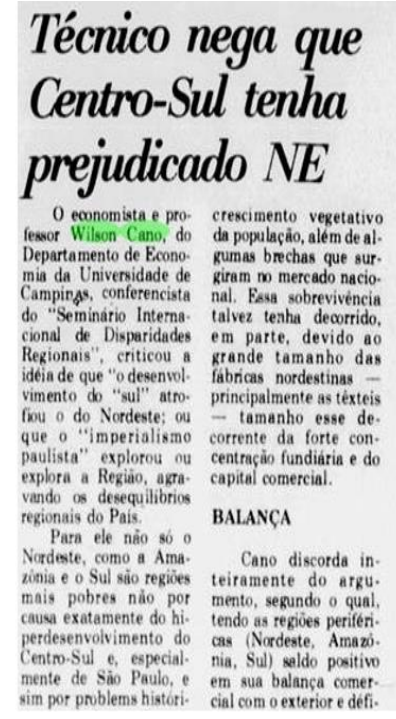

Ed. 4/9/1982

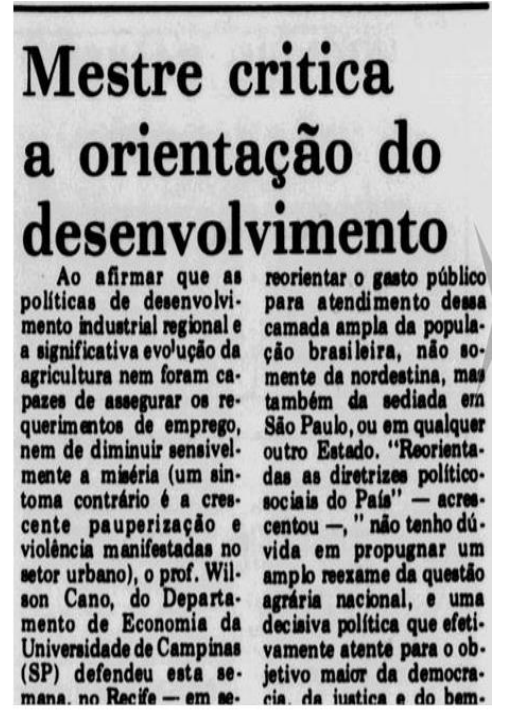

Ed. 14/3/1982

Fonte: acervo do Diario de Pernambuco. Disponível na Hemeroteca Digital Brasileira (Disponível em: memoria.bn.br. Acesso em: 31 jan. 2021).

(2) "Dentro de uma nação, sem fronteiras políticas ou alfandegárias internas, esse problema se torna complexo e não se pode apontar um suposto "imperialismo interno" sem precisar seus termos. Mas há que se entender que o verdadeiro problema do chamado "imperialismo interno" é o da concentração automática de capital por intermédio da concorrência capitalista que se processa em forma livre em um espaço econômico nacional unificado, em que os interesses privados de maior porte não são efetivamente regionais. Há, em síntese, a concentração em um centro dominante, que imprime os rumos decisivos do processo de acumulação de capital à escala nacional" (Cano, 2002, p. 132). 
O fato é que a refutação da tese do mito do imperialismo paulista constitui amostra significativa da abordagem de Wilson Cano para o problema regional no Brasil. Haja vista o transcurso de cerca de quatro décadas, desde então, objetiva-se demonstrar que os procedimentos por ele adotados podem ser úteis à realização de uma leitura contemporânea não do mito, em si, mas das interdependências que incidiram sobre a estrutura econômica das regiões brasileiras, com especial atenção dedicada ao Nordeste.

\section{Estrutura e dinâmica recentes das economias regionais do Brasil}

As transformações na natureza da interdependência entre São Paulo e a periferia nacional produziram e foram produzidas por novas determinações que incidiram sobre a questão regional e urbana no pós-1980 (Cano, 2011b). A maior diferenciação econômica entre as regiões do Brasil e a diversidade intrarregional subjacente (Araújo, 1982) requerem, por exemplo, a adoção de escalas diferenciadas para melhor compreender o padrão de atuação do Estado, do Mercado e da Sociedade na definição da estrutura e dinâmica subnacionais.

Após três décadas de crescimento e acelerada industrialização (1950-1980), a economia brasileira sofreria, a partir dos anos de 1980, impactos associados à modificação do padrão internacional hegemônico de acumulação de capital. Originada da elevação do grau de endividamento externo, a crise que então se iniciava foi desdobrada sob a forma de dificuldades fiscais e financeiras do setor público (Carneiro, 2002). Convém, então, identificar o que se passou em termos de uma economia nacional regionalmente integrada (Oliveira, 2008), a qual se veria diante de significativos desafios ocasionados por um contexto crítico (anos de 1980) e, depois, pela neoliberalização (anos de 1990 em diante).

Um dos agentes centrais da industrialização, o Estado padeceria de crescentes dificuldades para expandir e diversificar os elos intersetoriais emanados daquele processo. Muito disso se deveu ao esvaziamento da função de planejamento - que norteava ações para o desenvolvimento. Suprimiram-se as intervenções públicas que, anteriormente, levaram à desconcentração produtiva regional, face aos efeitos combinados da vulnerabilidade externa, da incapacidade fiscal e financeira do setor público e da galopante inflação (Cano, 2002; Cano, 2007; Almeida; Belluzzo, 2002).

A desaceleração da economia brasileira refletiu-se em termos espaciais: com a integração produtiva, efeitos recessivos foram disseminados pelas diversas regiões do país, embora em diferentes magnitudes e com espúrio sentido de desconcentração, resguardadas as exceções representadas pelos efeitos territoriais implícitos decorrentes de decisões locacionais de investimentos. Para tanto, em muito contribuiu a fragilização das instâncias executoras de políticas regionais (Monteiro Neto, 2005).

O Estado, debilitado em função da conjuntura adversa do decênio de 1980, seria reestruturado conforme os preceitos do Consenso de Washington, do que resultou um incontornável enxugamento institucional e a revisão dos padrões de intervenção direta na economia, mediante questionáveis privatizações (Cano, 2000). No início da década de 1990, consolidou-se, em escala nacional, a adesão ao neoliberalismo, marcada pela abertura comercial e financeira do país ao exterior, seguida pela subsequente neoliberalização (Brenner et al., 2012). 
Advindo um inexorável choque de competitividade na esteira da abertura, acreditava-se que a produtividade industrial brasileira alcançaria os patamares de referência internacional e o "ajuste" setorial seria, a posteriori, revertido em ganhos sociais (Bacha; Bonelli, 2005). Prevaleceu, ao contrário disso, um viés de desindustrialização, afetando, sobremaneira, o parque manufatureiro mais relevante do país, que era o de São Paulo (Sampaio, 2015).

Do ponto de vista espacial, fomentar-se-ia tão somente a infraestrutura necessária à articulação da economia de territórios dinâmicos às correntes de comércio mundial, apostando na reiteração de vantagens comparativas e contribuindo ainda mais para a observação de diferenciadas trajetórias subnacionais de crescimento (Galvão e Brandão, 2003). Já as unidades federadas, diante da incapacidade coordenadora do Governo Federal, passariam à condição de agentes ativos de indução do desenvolvimento regional. O federalismo brasileiro, ao contrário da proposta de cooperativismo da Constituição de 1988, assumiria uma faceta fratricida, por meio da Guerra Fiscal (Affonso e Silva, 1995). Com isso, acentuou-se no cálculo empresarial, efeitos das deseconomias de aglomeração que reforçaram a tendência de novos investimentos a se localizarem fora dos entornos metropolitanos, em especial o de São Paulo (Diniz, 2002).

Com a supressão das funções de intervenção e planejamento do Estado nos anos de 1980, confirmada pela neoliberalização, nos anos de 1990, a explicação de trajetórias regionais de desenvolvimento deve ser buscada menos nos aspectos políticos e institucionais e mais nas possibilidades de inserção competitiva e adequação funcional das regiões aos ditames da globalização (Oliveira e Werner, 2013). Embora as economias regionais tivessem convergido em relação à economia de São Paulo, a desconcentração produtiva do período foi apenas estatística (Cano, 2008).

Para Araújo (2000), o alheamento estatal quanto à condução de um efetivo processo regional de desenvolvimento levou à combinação entre uma herança de diferenciação - produto das insuficiências do modelo anterior - e um futuro de fragmentação territorial. Áreas dinâmicas, mobilizadas por acionamentos exógenos, coexistiam com lugares cuja atividade econômica estava sujeita a determinantes tradicionais (vulnerabilidade climática, modalidades tradicionais de gestão, etc.), a um baixo grau de desenvolvimento humano, a crises sociais e a uma atuação cada vez mais aprofundada do capital mercantil-rentista, travestido em formas mais modernas de acumulação amparadas em suporte dos poderes públicos locais.

A transição para a década de 2000 evidenciaria os limites da neoliberalização nas dimensões (i) macroeconômica, a contar da vulnerabilidade financeira à volatilidade especulativa de capitais atraídos para o país e da incapacidade de promover o esperado salto de produtividade e competitividade no setor industrial; e, (ii) espacial, dada a já mencionada tendência de fratura das relações inter-regionais estabelecidas durante o período da industrialização. Não por acaso, foi nesse período que projetos de impacto territorial das grandes empresas protagonizaram o desenvolvimento regional, suplantando as capacidades estatais (Oliveira; Werner, 2013).

A partir de 2003, reverberando um movimento que já vinha ocorrendo na América Latina desde o ano 2000, condições favoráveis passaram a estimular o crescimento da economia brasileira, associadas a um maior fluxo de capitais e à intensificação do comércio, em escala internacional, pelo menos até a crise financeira de 2008. Beneficiadas pelo "Efeito-China" e por uma forte desvalorização cambial à época das eleições presidenciais de 2002, as exportações ganharam impulso. Intensificaram-se as relações de comércio do tipo "Sul-Sul", muito embora não se tenha promovido 
modificações em uma pauta de produtos concentrada em commodities agrícolas e industriais (Cano, 2014), perfil reforçado - a despeito das tentativas de viabilizar adensamento de cadeias de valor no país - pela descoberta de petróleo na camada pré-sal.

Na perspectiva da demanda, verificou-se, ao longo da década de 2000, uma ampliação dos empregos formais e o aumento da renda das famílias. A valorização real do salário-mínimo disseminou um efeito-renda incrementado, ainda, por políticas sociais de transferência direta de recursos e pela expansão da concessão de crédito para consumo (Sarti; Hiratuka, 2011). Além disso, manteve-se, em geral, um estrito controle no que diz respeito à gestão dos fundamentos básicos da economia, disso resultando um grau de estabilidade macroeconômica que permitiu ao setor público nacional recobrar alguma capacidade de intervenção.

Verificou-se a retomada dos investimentos públicos e privados, tanto em infraestrutura econômica, quanto de caráter produtivo, apoiados pelo maior volume de crédito público para empresas, mesmo em presença da crise financeira mundial de 2008. Segundo Bielschowsky (2012), desse conjunto de determinantes resultou a ampliação da renda agregada, o que, pelo menos em tese, habilitaria o país a buscar um movimento de retomada do dinamismo, pautado na promoção da competitividade sistêmica.

Tais condições favoráveis expressam-se de maneira diferenciada, conforme seja o recorte regional escolhido. De acordo com o Gráfico 1, o Norte e o Centro-Oeste apresentaram maior dinamismo entre 2002 e 2018, crescendo, respectivamente, a taxas médias de 4,0\% a.a. e 3,9\% a.a., resultado superior à média nacional (3,0\% a.a.).

As economias do Nordeste e do Sul também tiveram os respectivos produtos internos se expandindo a taxas superiores à média nacional, ao passo que o Sudeste (2,5\% a.a.) apresentou menor dinâmica relativa, comprometida, especialmente, a partir de 2014. Esse é um quadro, aliás, generalizável para todas as regiões do país, embora o Norte e o Centro-Oeste, cujas bases produtivas são mais associadas à demanda internacional, tenham sofrido menor impacto relativo (Gráfico 1).

Gráfico 1

Evolução (2002=100) e taxa de crescimento (\%) do PIB, segundo macrorregiões, 2002-2018

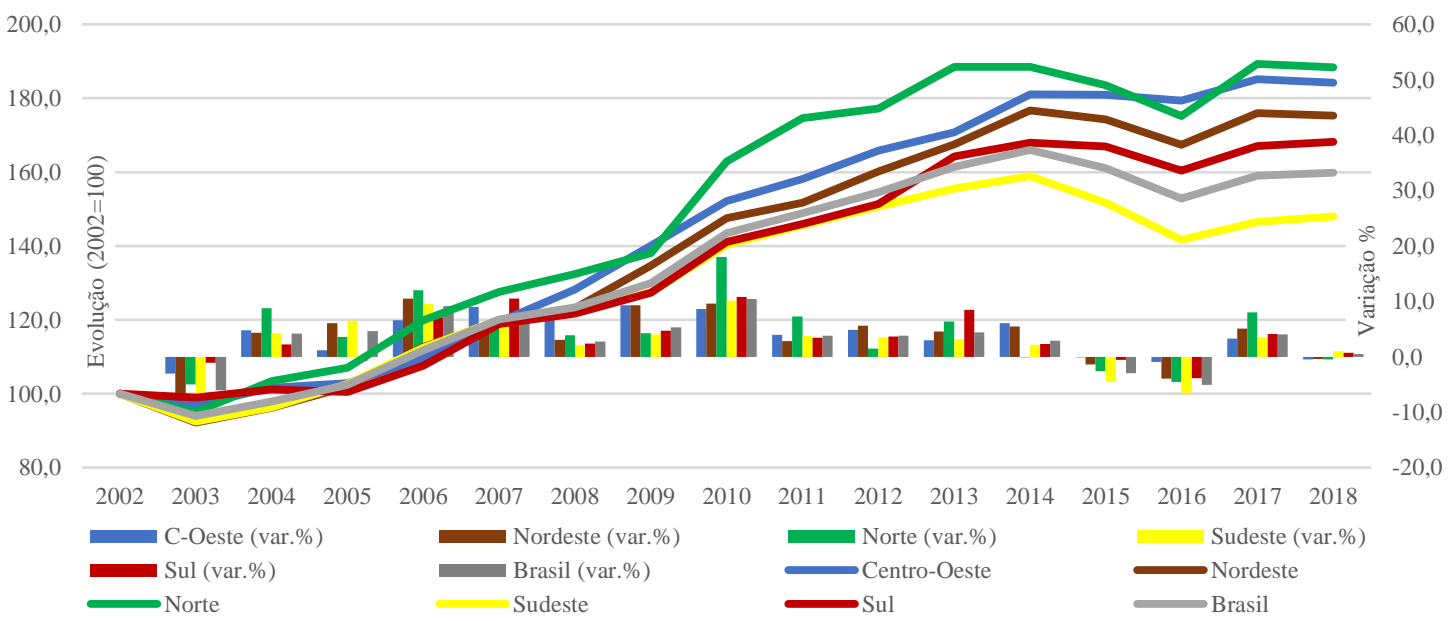

Fonte: Elaboração própria com base em Contas Nacionais e Contas Regionais - IBGE. 
Não obstante o recorte macrorregional apresentado no Gráfico 1, é conveniente destacar as bases subregionais herdadas do período anterior, definidas pela inserção internacional seletiva de territórios dotados de vantagens comparativas estáticas, frente aos parâmetros impostos pela globalização. Tome-se, por exemplo, a vigorosa expansão agropecuária no Oeste da Bahia, no Sul do Maranhão e no Sul do Piauí (Favareto, 2019). Nelas, onde se situam os cerrados nordestinos, a expansão econômica deu-se em função da exportação de soja e da pecuária, ao que é possível também incorporar culturas outrora tradicionais e, agora, igualmente geridas em bases modernas, como o milho e o algodão (BNB, 2014).

$\mathrm{Na}$ esteira da abertura comercial e financeira do país, esse resultado evidencia e aprofunda a existência de vários "Nordestes", cujos germes já estavam postos em meados dos anos de 1980, quando os polos e complexos agroindustriais constituíram importantes fontes de dinamismo, chancelando a coexistência de atividades tradicionais e atividades modernas (Araújo, 2000). As primeiras em crise e as últimas apresentando desempenho relacionado aos mercados internacionais, sobrelevando, à escala sub-regional, determinações exógenas - não necessariamente oriundas de São Paulo.

Muito embora o Efeito-China fosse fundamental para vitalizar as regiões exportadoras, um conjunto adicional fatores, entre os quais algumas políticas regionais implícitas, subvencionou a periferia nacional, a partir de 2004. No caso do Nordeste, a criação de empregos formais, a implantação de importantes empreendimentos industriais e estruturadores, a política de valorização real do salário-mínimo e as transferências diretas de renda foram fundamentais (BNB, 2014). A isso somaram-se a maior concessão de financiamento por parte do Banco Nacional de Desenvolvimento Econômico e Social (BNDES), além do programa habitacional Minha Casa, Minha Vida e as obras de construção de estádios de futebol para a realização da Copa do Mundo de 2014.

Apesar da considerável redução da pobreza e melhoria no nível de vida, observáveis em todas as regiões do país, persistiram desafios relacionados à sustentação do avanço proporcionado, majoritariamente, por políticas regionais implícitas. Guimarães Neto e Oliveira (2018) apontam que, ao contrário do quadro de crescimento verificado na primeira década do século XXI, a desaceleração dos anos de 2010, tal como ilustra o Gráfico 1, reforçou algumas premências estruturais. No caso do Nordeste, consta a preocupação em articular a antiga base produtiva local às plantas produtivas dos segmentos de petróleo e gás, petroquímica, farmoquímica, automotiva e naval, cujos investimentos, inclusive, foram comprometidos por investigações jurídico-policiais.

Por outro lado, as ações governamentais estiveram longe de evidenciar a articulação proposta pela Política Nacional de Desenvolvimento Regional (PNDR). O desenvolvimento regional brasileiro segue carecendo de um "norte político", dada a pulverização de intervenções não-intencionadas, ao que se agregam dificuldades de governança e coesão (Guimarães Neto, 2012). A ausência de uma política de desenvolvimento regional efetiva terminou por justificar a adesão irrefreada das unidades federadas de todo país aos instrumentos de subsídios e concessões fiscais para atrair investimentos. Nesse contexto, as frações de capital - em especial as de maior porte e de origem extrarregional aproveitaram-se da guerra fiscal (Vieira, 2012), o que representa nada menos do que a transferência (direta e indireta) de recursos públicos para a composição de caixa e portfólio de grupos empresariais. 
Um ponto adicional a assinalar é que, desde a crise de 2008, a economia mundial vem tentando - sem sucesso - recuperar-se do baque sofrido pelo caráter sistêmico (econômico, geográfico, político, social cultural, etc.) daquela retração. Medidas ainda imprecisas e de pouca efetividade quanto à capacidade de regulação do sistema financeiro internacional não apontam para a reversão da dominância da Finança sobre decisões empresariais e de consumo. Tanto é assim que, a partir de 2014, a desaceleração da economia brasileira se reverte em uma crise que, conforme o Gráfico 1, alcança o perigeu no biênio 2015-2016.

\section{Uma releitura contemporânea das objeções ao mito do imperialismo paulista}

Os argumentos que compunham a réplica à tese do mito do imperialismo paulista (seção 2) foram empregados por Wilson Cano à luz do processo de industrialização da economia nacional. Esse quadro se alterou após 1980, quando, baseando-se nos traços distintivos da agenda de pesquisa que ele empreendeu, procurou-se demonstrar que o país se afastou de uma rota sustentada e espacialmente coordenada de desenvolvimento (seção 3), em uma quadratura histórica na qual a acumulação capitalista vem sendo regida por outro sentido hegemônico.

Trata-se, pois, de um quadro situacional que recomenda uma análise renovada acerca das interdependências regionais da economia brasileira. Conforme destacou-se na Introdução, aplica-se tal arcabouço ao contexto recente do Nordeste não para reavivar o "mito", mas sim para buscar caminhos analíticos que possibilitem encaixar o exame da questão regional brasileira ao problema do desenvolvimento nacional.

Essa abordagem se inicia, portanto, com o exame dos fluxos financeiros inter-regionais. Segundo Monteiro Neto (2008), é possível subdividi-los em: (i) recursos de agentes privados, obtidos, majoritariamente, via liberações creditícias no sistema financeiro (público e privado); e (ii) recursos federativos, oriundos tanto de arrecadação tributária própria dos entes subnacionais, de transferências intergovernamentais e de convênios multilaterais públicos e privados, nacionais ou internacionais, como de repasses do pacto federativo, definidos e centralizados em fundos constitucionais.

No caso das liberações creditícias, uma aproximação pode ser feita mediante o exame do histórico de desembolsos regionais do BNDES como proporção do total nacional ${ }^{3}$. O Gráfico 2 apresenta, em médias móveis quinquenais, as participações relativas da oferta de crédito no Nordeste em relação ao total no Brasil para o período 1995-2020. Como se vê, o ano de 2008 dá partida a uma inflexão na trajetória de descenso da participação nordestina no total nacional de desembolsos do BNDES. Até então, a orientação estratégica do banco era a de dar suporte financeiro ao Programa Nacional de Desestatização ${ }^{4}$. Parte relevante das empresas-alvo do programa - Companhia Siderúrgica Nacional, Açominas, Cosipa e Embraer - se encontrava no Sudeste do país. Isso, mais a acentuação da fragilidade competitiva do tradicional parque produtivo do Nordeste, ajudou a definir a queda do patamar de $12,1 \%$, na média quinquenal de 1995-1999, para 8,2\% do total dos desembolsos entre os anos 2004-2008.

(3) Há outras fontes relevantes de captação de recursos creditícios a serem consideradas. É o caso do Banco do Nordeste do Brasil (BNB), cujo fomento financeiro se destina, sobretudo, a segmentos compostos por empresas de pequeno porte e da agropecuária.

(4) Medida Provisória n. 155 de 1990. 
Gráfico 2

Médias móveis quinquenais da participação dos desembolsos realizados pelo BNDES no Nordeste, relativamente ao Brasil, 1995-2020 (em \%)

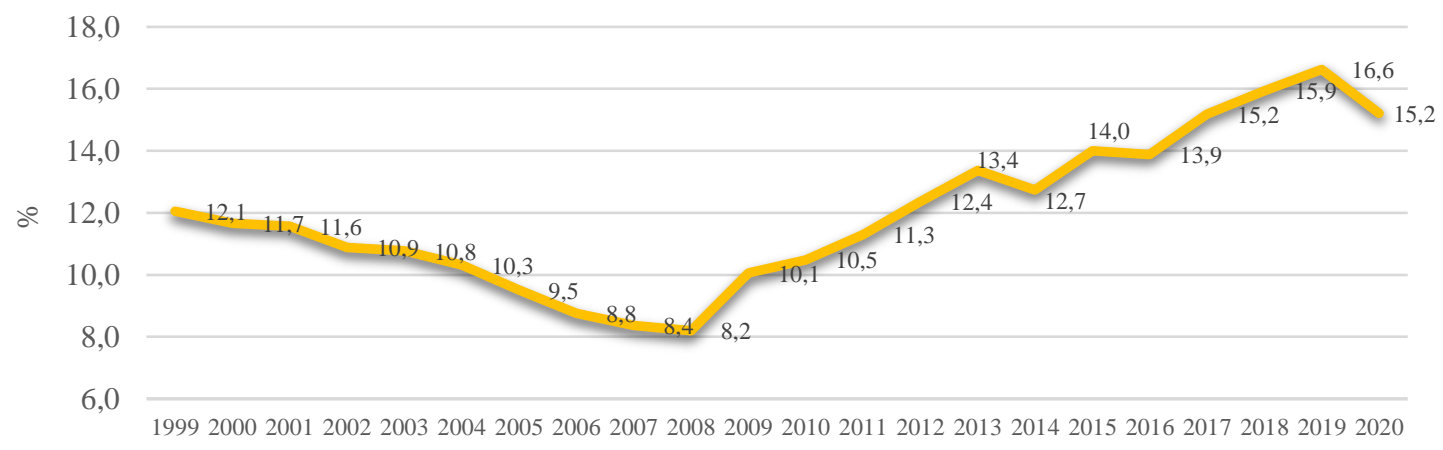

Fonte: Elaboração própria, com base nas estatísticas operacionais do Sistema BNDES.

Distinto é o quadro que se verifica ao longo da década de 2010. A despeito dos impactos da crise financeira internacional de 2008, e de breves decaídas em 2014-2015 e 2016-2017, a participação do Nordeste no total de desembolsos creditícios nacionais passou a ser ascendente, alcançando 16,6\% na média de 2015-2019 (Gráfico 2), tendo como principais elementos explicativos dessa reviravolta a realização de investimentos estruturadores na esteira das determinações apontadas na seção 3, com destaque para as refinarias de petróleo, termelétricas, estaleiros e para a constituição do parque produtivo associado à geração de energia eólica (Guimarães et al., 2014).

Cumpre, então, concluir que, observados desde a ótica dos recursos creditícios liberados pelo BNDES, os fluxos financeiros inter-regionais, especialmente aqueles orientados ao financiamento de projetos empresariais, estiveram, nos últimos anos, em favor da sustentação da dinâmica econômica no Nordeste brasileiro. Não se pode, entretanto, desconsiderar o fato de que o financiamento de empreendimentos na região reforçou o controle extralocal e mesmo internacional de capitais - o que é, aliás, um subproduto do processo de integração produtiva (ver, adiante, as observações sobre o terceiro argumento do mito).

Quanto aos recursos federativos, esperar-se-ia que a retomada do crescimento econômico com base em novas cadeias de valor e, em certos casos, na renovação de atividades tradicionais, promovesse melhor base de arrecadação tributária no Nordeste. Além disso, não se pode deixar de ter em vista o papel relevante exercido pelas condições de desigualdade regional na determinação das transferências intergovernamentais e dos repasses associados aos fundos constitucionais. Com efeito, Monteiro Neto (2014) revela que, no ano 2000, a base de arrecadação tributária própria dos estados da região equivalia, em média, a 48,5\% da média nacional per capita, índice que se elevou a 52,8\% no ano de 2010. Quando acrescidas as transferências intergovernamentais, a participação de recursos per capita dos estados nordestinos na média nacional se elevou a $65 \%$ e $73 \%$ nos respectivos anos.

De acordo com as informações apresentadas no Gráfico 3, a participação nordestina no total das receitas orçamentárias correntes foi de, em média, 16\% no período 2013-2017, alcançando, em 2016, a ordem de 16,9\%. Essa tendência de alta em tão curto período reflete a combinação entre uma conjuntura crítica para a economia do Sudeste e, sobretudo, a entrada em operação, no Nordeste, do 
bloco de investimentos estruturadores que haviam sido anunciados, na região, a partir de meados dos anos de 2000.

\section{Gráfico 3}

Participação dos estados nordestinos no total nacional de receitas correntes do setor público, antes e depois das transferências intergovernamentais, 2013-2017

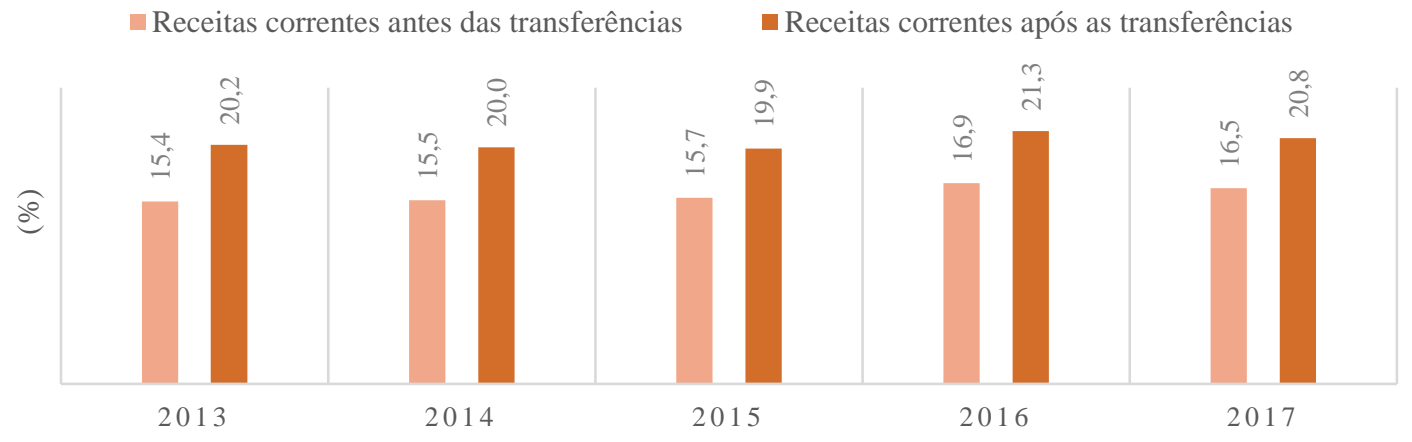

Fonte: Elaboração própria com base no Siconfi/STN.

Quando consideradas as transferências, registrou-se uma elevação média de 4,4\%, no período, das receitas correntes dos estados do Nordeste. Cumpre lembrar, no entanto, que os resultados apontados no Gráfico 3 tenderiam a ser mais robustos, não fosse o recrudescimento da Guerra Fiscal e o viés de centralização de recursos fiscais no Governo Central (Santos, 2017), determinantes para que a arrecadação própria subnacional não tenha alcançado pleno potencial. Com isso, o ganho de relevância das transferências intergovernamentais, em termos de composição orçamentária corrente nos estados, indica maior ingerência federal no processo decisório da política subnacional, refletindo a fragilidade governativa subnacional para o desenho e execução de políticas públicas - fenômeno que não se verifica, exclusivamente, no Nordeste, mas naqueles estados (e municípios) de menor densidade econômica do país.

Dada a fragilidade estrutural das finanças públicas subnacionais em regiões menos desenvolvidas, como o Nordeste, faz-se relevante considerar que os aportes adicionais representados pelo Fundo de Participação dos Estados e pelo Fundo de Participação dos Municípios, além do Fundo de Desenvolvimento do Nordeste, representam uma expressão do grau de dependência em relação ao Governo Federal. Não há, contudo, garantias de que os recursos recebidos mediante transferências intergovernamentais e enviados via fundos constitucionais sejam utilizados para mobilizar a base local/regional de oferta de bens/serviços.

Quando se considera que um dos resultados estruturais da industrialização foi o processo de integração regional do mercado brasileiro (Guimarães Neto, 1989), faz-se necessário qualificar as interdependências que dele derivam, o que Cano (2008) realizou com base no balanço entre efeitos de estímulo, bloqueio e destruição de estruturas produtivas especializadas. Apesar das limitações em termos de robustez e confiabilidade das bases de dados disponíveis de comércio interestadual ${ }^{5}$, a

(5) O estudo do comércio interestadual permite identificar, por exemplo, o papel exercido por centros regionais de distribuição, como é o caso do estado de Pernambuco em relação ao Nordeste oriental (Galvão, 2005). Apesar dos esforços de pesquisadores de diversos 
análise doravante permite, ao menos, atualizar os aspectos associados ao núcleo do segundo argumento do mito do imperialismo paulista, qual seja, aquele centrado na resultante do cotejo das balanças de comércio internacional do Nordeste e de São Paulo.

Conforme destacado na seção 2, afirmava-se que o saldo positivo da balança de comércio internacional nordestina financiava o déficit comercial externo da economia paulista. Essa é uma concepção que, ao mesclar as escalas internacional e inter-regional, prescinde de algumas considerações preliminares. No que se refere às exportações para o exterior, claro está que as regiões Norte e Centro-Oeste são aquelas que se destacam, e isso sem que haja a ruptura com o sentido territorial de uma acumulação subordinada ao rentismo e promotora de despossessão, o que Tavares (1999) denominou de "fuga para a frente". Quanto às importações provenientes do exterior, as determinações da guerra fiscal escancararam as portas e os portos do país à entrada de mercadorias que reforçaram, ainda mais, a pressão competitiva à qual está submetido o que resta do parque manufatureiro nacional. Esses são aspectos que definem uma interatividade específica para o comércio interestadual, cujo arrazoamento escapa, pelos motivos antes mencionados, a análises que se pretendam objetivas.

A modo de ilustração, resta, então, situar o saldo e a corrente de comércio internacional, agregados para os estados do Nordeste e para o estado de São Paulo ao longo do período compreendido entre 1997 e 2020 (Gráfico 4).

\section{Gráfico 4}

Saldo e corrente de comércio de internacional dos estados do Nordeste e do estado de São Paulo, 1997-2020

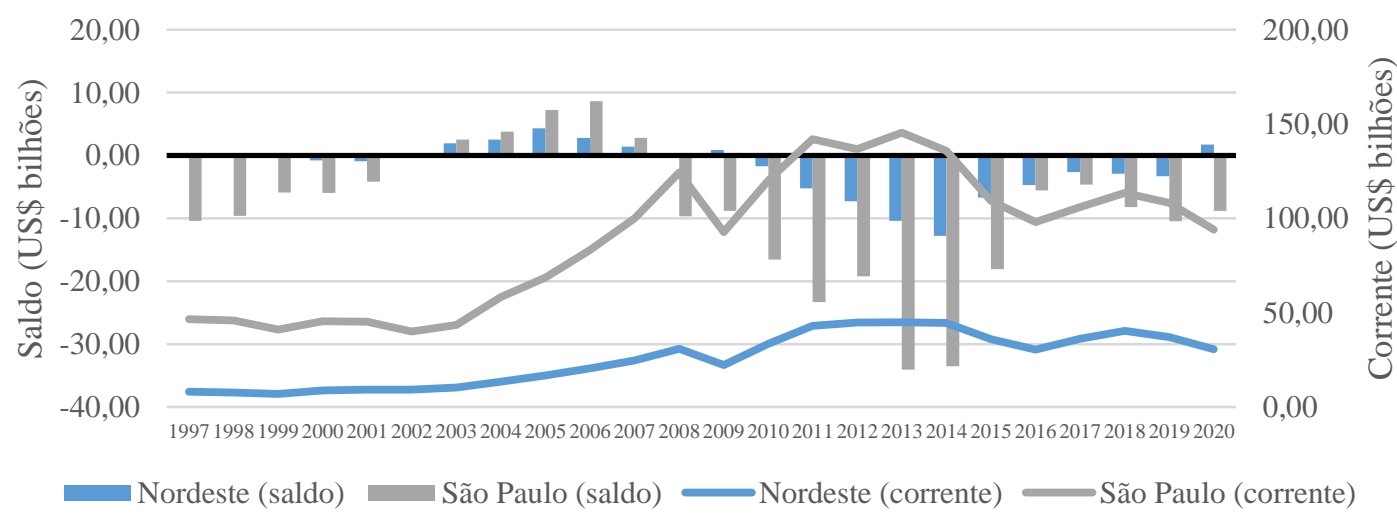

Fonte: Elaboração própria com base no Sistema Comex Stat, Governo Federal.

Um primeiro aspecto a ressaltar, observando-se o Gráfico 4, é que a corrente de comércio internacional (somatório dos valores de exportação e importação) da economia de São Paulo é maior do que a soma da corrente de comércio de todas as economias estaduais do Nordeste - uma

órgãos, como o Instituto de Pesquisa Econômica Aplicada (IPEA) e algumas Secretarias Estaduais de Fazenda, persiste um impasse quanto à unificação e normalização de uma abordagem metodológica e empírica capaz de tornar comparáveis, sobretudo, os resultados do Imposto sobre a Circulação de Mercadorias e Serviços (ICMS). A despeito de tais problemas, ver Romeu (2006) e Maranhão e Romão (2014) para uma abordagem matricial do comércio interestadual. Uma possível alternativa, para estudos futuros, é o uso das informações de notas fiscais eletrônicas. 
característica estrutural que foi ainda mais acentuada a partir de 2002. Ademais, a expansão nominal desse indicador, seja para o Nordeste, seja para São Paulo, foi expressiva, mais que triplicando e duplicando, respectivamente, na década de 2000. Em ambos os casos, essa foi uma decorrência direta do Efeito-China, impactando as exportações de produtos primários e de baixo valor agregado na região e no estado, especialmente após os efeitos provocados pela abertura comercial/financeira - que levou à reestruturação de setores tradicionais, como o têxtil - e pelo uso, por alguns anos, de uma taxa de câmbio valorizada como âncora monetária, o que sustentou o barateamento de importados.

As correntes de comércio nordestina e paulista sofreram impactos ocasionados pela crise de 2008, mas logo recobraram o viés de alta, outra vez interrompido a partir de 2014. À diferença dos anos 2000, a década de 2010 viu invertido o resultado da balança comercial, indicando um quadro deficitário em ambos os recortes espaciais considerados. No interregno 2002-2007, o superávit paulista foi maior que o nordestino. Após 2008, houve registro de superávit comercial apenas em 2009 e 2020, e isso no Nordeste - proporcionando, no entanto, uma cobertura de apenas 9,8\% e 19,5\%, respectivamente, do déficit de São Paulo (Gráfico 4).

Os saldos negativos nas balanças comerciais nordestina e paulista, durante os anos de 2010, requerem melhor diferenciação em termos de fatores explicativos. Enquanto, em São Paulo, deveuse à centralidade do porto de Santos, ao aprofundamento da desindustrialização e mesmo aos efeitos da espúria desconcentração produtiva regional no Brasil iniciada nos anos de 1980, no Nordeste aquela condição reflete as demandas de bens, serviços e equipamentos para a implantação do bloco de investimentos estruturadores que renovou a economia regional, em especial a transformação industrial.

O terceiro argumento do mito do imperialismo paulista era o de que os diferenciais de produtividade e de preços (de produtos manufaturados) embasariam a transferência de renda da periferia à economia dominante. Essa é uma ideia que, para a contemporaneidade, pode ser decomposta em duas partes. Em primeiro lugar, é bom lembrar que, após o processo de integração produtiva, a concepção de região como uma formação socioeconômica isolada e autônoma foi sendo substituída pela ideia de um espaço nacional regionalmente diferenciado. Os mesmos grupos empresariais oligopolistas que, sediados em São Paulo, lideravam a industrialização brasileira, passaram a se beneficiar de incentivos para consolidar, polarizar e hegemonizar uma divisão interregional do trabalho no país (Oliveira; Reichstul, 1973).

Por essa razão, mais do que concorrência, o que se viu a partir de meados do século XX foi uma coerência decisória que solidarizou as estruturas e dinâmicas subnacionais no Brasil (Oliveira, 2014) e que marcou o início do processo virtuoso de desconcentração produtiva a partir da década de 1970 (Cano, 2008). Não haver sustentado esse processo revela a incapacidade de as políticas regionais ampararem as expectativas empresariais quanto a retornos de investimento, especialmente diante das decisões defensivas dos 1980 e dos 1990, que terminaram por reforçar o sentido mercantil-rentista de acumulação (Cano, 2011b).

Em segundo lugar, embora seja possível identificar distintas produtividades entre estruturas industriais nas economias regionais brasileiras, a ideia de que elas baseiam a prática de preços diferenciais favoráveis à indústria paulista deve ser completamente relativizada pelo fato de haver, 
atualmente, o exercício de um controle exógeno de capital dos principais empreendimentos situados no Nordeste.

Ainda assim, convém averiguar como se deu a evolução da produtividade industrial em termos regionais. Para tanto, procedeu-se ao cotejo da relação entre o valor da transformação industrial e o número de pessoas ocupadas - aqui considerada uma aproximação ao conceito de produtividade - na indústria de transformação do Nordeste e do estado de São Paulo. A resultante desse cálculo, feito em médias móveis quinquenais para o período 1996-2018, é exposta no Gráfico 5.

Gráfico 5

Produtividade da indústria de transformação do Nordeste em relação à indústria de transformação de São Paulo, em médias móveis quinquenais, 1996-2018 (em \%)

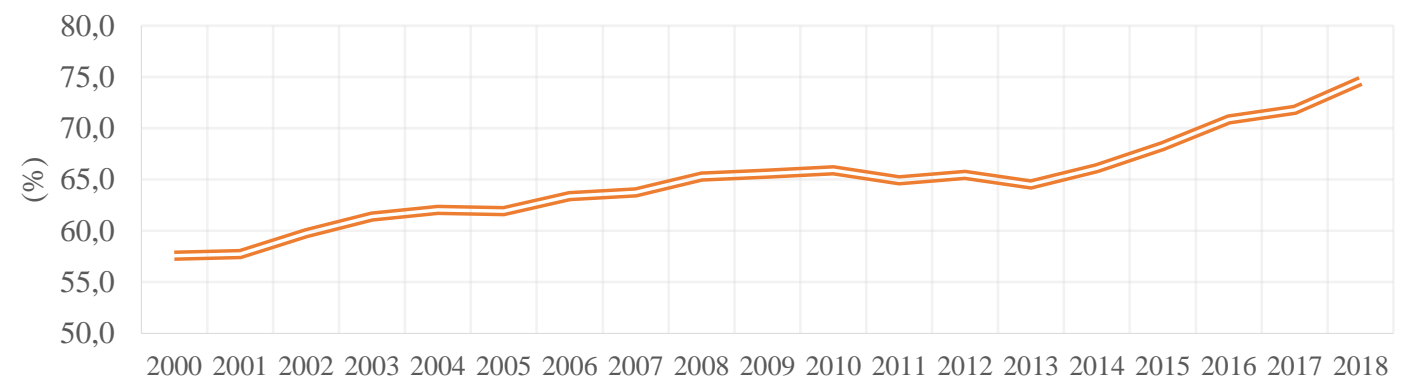

Fonte: Elaboração própria com base em Pesquisa Industrial Anual (PIA) - IBGE.

Nota: consideram-se os empreendimentos da indústria de transformação, classificados de acordo com a CNAE 1.0 (até 2006) e CNAE 2.0 (após 2007), que possuam 5 ou mais pessoas ocupadas.

O que se vê no Gráfico 5 é uma consistente trajetória de convergência da produtividade da indústria de transformação do Nordeste em relação à indústria de transformação paulista. Esse resultado é particularmente expressivo a partir de 2013, quando entrou em operação boa parte dos empreendimentos estruturadores cuja implantação, na região, remete a meados da década de 2000. Apesar disso, convém destacar que a produtividade industrial nordestina ainda é, em geral, inferior a $75 \%$ da produtividade média da indústria de transformação paulista, a qual é, sabidamente, defasada em relação ao benchmarking internacional, além de ter sido alvejada pelos desdobramentos da desconcentração espúria, da abertura comercial e financeira e da desindustrialização.

O grau de adensamento produtivo, medido pela relação entre o valor da transformação industrial (VTI) e o valor bruto da produção industrial (VBP), complementa a perspectiva da transferência de renda inter-regional aventada pela tese do mito. Para o IEDI (2007), essa relação indica o maior/menor uso de insumos locais/extralocais que, em última instância, determinam uma transferência de renda como contrapartida à aquisição de materiais necessários à produção no âmbito do recorte escalar considerado. Portanto, esse quociente, apresentado no Gráfico 6 para o período 1996-2018, antecipa o quanto da produção industrial foi agregado/transformado no país, na região ou no estado.

Há, no Gráfico 6, ao menos três comportamentos que merecem destaque. O primeiro diz respeito à trajetória descendente da relação VTI/VBP para o Brasil e o estado de São Paulo entre 1996 e 2004, movimento que, para o Nordeste, se inicia de forma mais consistente a partir de 2000. Após 
2004, é na região que ocorre um maior adensamento produtivo, o qual eleva-se, inclusive, por sobre o patamar verificado para o país e a economia paulista, até o ano de 2012. Começa, então, uma nova tendência de baixa, que perdura até o ano de 2018.

Tem sido, portanto, um desafio constituir maior densidade produtiva endógena em todo o país, indicando a perda de rendimentos produtivos para o exterior. $\mathrm{O}$ mesmo pode ser dito para a economia do Nordeste, que, a despeito da convergência de produtividade industrial, não sustentou a internalização dos elos intersetoriais das cadeias de valor ali implantadas nos últimos anos (Gráfico 6).

O fato é que a abertura comercial dos anos de 1990 invalidou quaisquer políticas protecionistas que haviam vigorado durante o processo precedente de industrialização (Cano, 2014). O quadro mais agravado é o da economia paulista, que, conforme visto, inseriu-se na corrente de comércio internacional com o registro generalizado de déficits entre 1997 e 2020, exceto no breve interregno em que vigorou o Efeito-China. Foi da China que provieram os efeitos concorrenciais mais devastadores sobre as tradicionais indústrias paulistas e nordestinas, notadamente aquelas produtoras de bens de consumo não-duráveis, como a fabricação de alimentos e de têxteis (Oliveira, 2014).

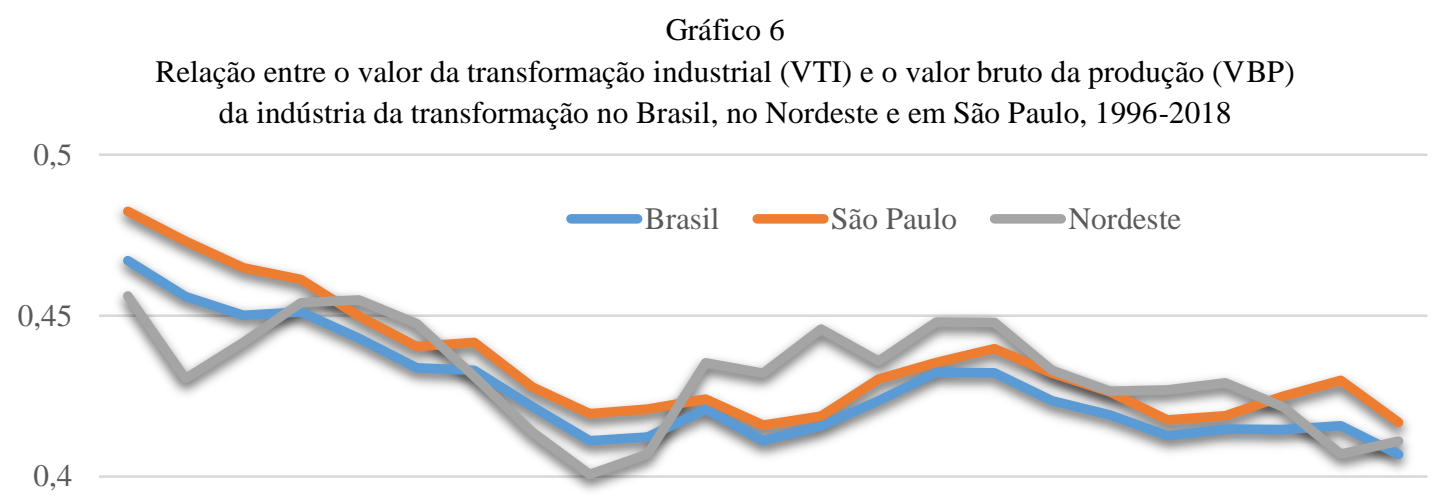

0,35

19961997199819992000200120022003200420052006200720082009201020112012201320142015201620172018

Fonte: Elaboração própria com base em Pesquisa Industrial Anual (PIA) - IBGE. Nota: consideram-se os empreendimentos de acordo com a CNAE 1.0 (até 2006) e 2.0 (após 2007) com 5 ou mais pessoas ocupadas.

O "alívio do fardo" de adquirir mercadorias em São Paulo não foi, portanto, substituído por uma maior capacidade de instituir elos produtivos no território do Nordeste, sendo inescapável acorrer a fornecedores asiáticos, muitos deles atuando em centros comerciais tradicionais e modernos das maiores cidades da região. Com efeito, a estruturação global de cadeias de valor faz com que diversas partes do mundo sejam vinculadas em uma lógica funcional à acumulação flexível e financeirizada de capitais à escala mundial, o que ajuda a explicar o porquê de a relação VTI/VBP ter sido declinante mesmo em uma economia reestruturada por importantes investimentos, como é o caso nordestino (Gráfico 6).

Há, pois, uma tendência de que se fragilize ainda mais a coerência macrodecisória interregional sobre a qual esteve assentado o processo de industrialização brasileiro. Isso tem um sentido 
claro: em vez de comprar mercadorias ou mesmo contribuir com o fornecimento de insumos e serviços à produção manufatureira localizada em São Paulo, as economias periféricas nacionais se veem diante de uma crescente necessidade de negociar - em evidente posição de desvantagem - com os operadores hegemônicos das cadeias globais de valor que as acionam. Entre eles estão os capitais chineses, cujos interesses e vultosos investimentos em infraestrutura objetivam tão somente encontrar oportunidades rentáveis de inversão - o que pressupõe rodadas regulatórias neoliberalizantes - e acelerar o escoamento de bens agropecuários (Werner, 2020).

O último ponto da tese do mito do imperialismo paulista é o de que o crescimento de São Paulo se dava às custas do excedente periférico. Essa ideia foi contradita por Guimarães Neto (1997), para quem, antes da integração produtiva,

O que se tinha eram espaços distintos, integrantes de um mesmo sistema comercial, com sua individualidade. No segundo momento, tais espaços constituem parte de um único sistema de produção, geralmente com diferenciações que dizem respeito a uma hierarquia no interior desse sistema, ou a uma divisão espacial de trabalho (Guimarães Neto, 1997, p. 40-41).

Trata-se de um contra-argumento capaz de condensar os anteriores e que tem, na trajetória de crescimento das economias nordestina e nacional, uma demonstração empírica das mais interessantes: a integração produtiva do mercado brasileiro, a julgar pelo cotejo do ritmo expansivo do PIB do Brasil e do Nordeste (Gráfico 7), segue vigente. Isso apesar de percalços causados pelo comprometimento do Estado Nacional, nos anos de 1980; do viés de fragmentação causado pela inserção competitiva, no pós-1990; da ausência de coordenação de políticas regionais nos anos posteriores a 2000; e do pronunciado sentido neoliberalizante que vem configurando a implantação de infraestrutura (energia e logística, principalmente) em regiões exportadoras, o qual foi intensificado após 2010.

Gráfico 7

Taxa anual de crescimento (em \%) do PIB do Brasil e do Nordeste, 1960-2010 (em médias móveis quinquenais)

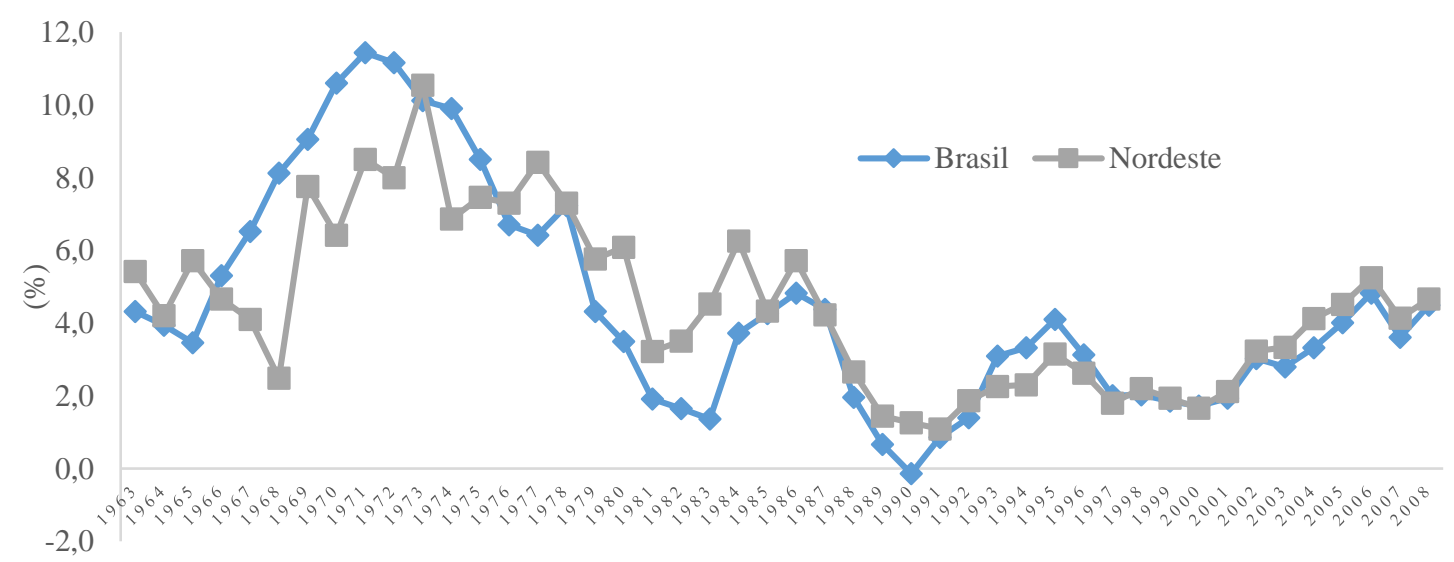

Fonte: Elaboração própria com base em Contas Nacionais e Contas Regionais - IBGE.

A solidariedade entre a dinâmica de crescimento das economias do Nordeste e do Brasil nos cinquenta anos posteriores à integração produtiva, indicada no Gráfico 7, coloca a necessidade de compreender as nuances dessa evolução, em especial os momentos de descolamento do crescimento nordestino e nacional. Dessa aparente dissociação emergiu a identificação de dois movimentos 
marcantes na integração produtiva do mercado brasileiro: a desconcentração virtuosa da década de 1970 e a desconcentração espúria dos anos de 1980 (Cano, 2007a; Cano, 2007b), complementados, nos anos de 1990, pela já mencionada tendência de fragmentação (Pacheco, 1998). De qualquer maneira, no caso da evolução do Nordeste, é marcante a correlação entre a evolução do PIB do Nordeste e do Brasil. Além, disso, convém ressaltar os efeitos favoráveis proporcionados pela política da Sudene entre 1966-1973 e 1977-1984, o que, por si só, invalidaria a tese regionalista.

O enfoque dos efeitos de estímulo, bloqueio/inibição e destruição (Cano, 2008), aplicado a um período que cobre boa parte dos anos de 2000 e 2010, em muito se beneficia de avanços metodológicos relevantes, especialmente no que se refere aos dados subnacionais do PIB. Conhecidos os determinantes e a dinâmica regional recente no país, discutidos na seção 3, é possível diferenciálos à escala macrorregional, tal como ilustra o Gráfico 8, mas também mesorregional.

O Gráfico 8 revela um sentido de desconcentração produtiva que, favorável a todas as regiões brasileiras, deu-se em detrimento do Sudeste, cujo PIB passou de 57,4\% do total do país, em 2002, para 53,1\% em 2018, redistribuição que se concretizou nos seguintes ganhos relativos de participação: Centro-Oeste (ganho de 1,3 pontos percentuais), Nordeste (1,2 p.p.), Sul (0,9 p.p.) e Norte (0,8 p.p.).

Gráfico 8

Participação macrorregional no Produto Interno Bruto (PIB) do Brasil, 2002-2018 (\%)

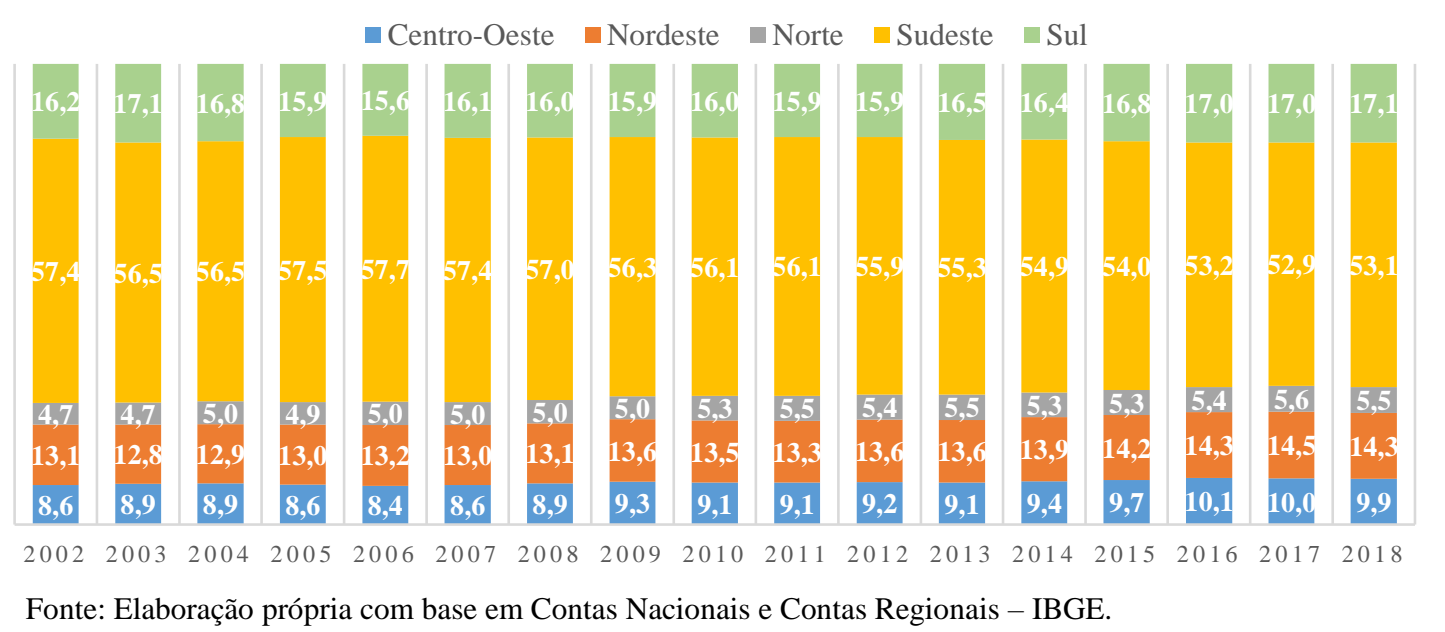

A base de dados utilizada no Gráfico 8 permite qualificar esses resultados ao ser adotado, por exemplo, um recorte mesorregional. Nesse sentido, é possível afirmar que, das dez mesorregiões que apresentaram maior dinamismo entre 2002 e 2018, nove delas estavam vinculadas às atividades agroexportadoras (soja e pecuária) e uma à exploração de petróleo. Além disso, os casos de menor dinamismo foram aqueles das mesorregiões metropolitanas, em especial as do Sudeste do país, que cederam espaço econômico para uma rede de cidades médias que, exercendo novo papel organizador e ofertando bens e serviços públicos antes inexistentes, foi-se conformando pelo território nacional.

A região Nordeste participa com quatro daquelas nove mesorregiões de maior dinamismo relativo, quais sejam, o Sudoeste Piauiense (8,9\% a.a., entre 2002 e 2018), o Sul Maranhense (6,5\% a.a.), o Sudeste Piauiense (5,9\% a.a.) e o Extremo Oeste Baiano (5,8\% a.a.). Trata-se, portanto, de 
um crescimento que se dá no sentido de robustecer os elos regionais relativos à demanda internacional de produtos primários.

De posse de uma base informacional mais fiel às dinâmicas subnacionais, convém, então, recalibrar as argumentações concernentes ao suposto benefício paulista, a contar de um melhor entendimento acerca das interdependências multiescalares que se processam pelo país. O iniludível indício de aprofundamento da seletividade dinâmica de algumas poucas regiões brasileiras alerta para a imperativa necessidade de coordenar de fato a distribuição de condições econômicas no vasto território brasileiro, pressuposto, é claro, o desejo de recolocar o Brasil, novamente, em uma rota de desenvolvimento.

\section{Conclusões}

A tese do imperialismo paulista foi uma estratégia discursiva das elites periféricas que visava uma sobrevida aos pactos de dominação e preservação de estruturas socioeconômicas erigidos em formações regionais cada vez mais pressionadas pela integração produtiva nacional. Ao refutá-la, Wilson Cano legou uma das contribuições mais relevantes ao entendimento da questão regional no Brasil.

Desbaratar as narrativas e argumentações regionalistas era um passo fundamental para que se pudesse situar o verdadeiro problema ante o qual as regiões brasileiras - acionadas comercial e produtivamente pelo pioneirismo da industrialização concentrada em São Paulo - estavam se deparando. Em vez de acusar defasagens na busca imitativa e autonomista do padrão hegemônico de acumulação que emanava da economia paulista, mais apropriado seria diagnosticar limites e possibilidades ocasionados por esse movimento, de maneira a planejar os efeitos espaciais do processo nacional de desenvolvimento em curso, preparando o país e suas regiões para o desafiador cenário de disputas interestatais.

Quase quatro décadas transcorreram desde que os primeiros e acalorados debates, centrados na contra-argumentação do imperialismo paulista, tiveram lugar. Desde então, novas determinações sobre a questão regional brasileira impediriam, por si só, reavivar o mito - embora ainda existam entusiastas e saudosistas das teses que o amparavam. Hoje, com a neoliberalização, os desafios parecem ainda mais vultosos, haja vista o comprometimento de dispositivos públicos em face dos requerimentos da financeirização.

Ao inibir a instrumentação apropriada de uma estratégia de desenvolvimento, tal como ocorrera - mesmo que de forma parcial - durante a industrialização, periga-se perenizar um padrão de inserção internacional incapaz de proporcionar a suficiência dinâmica requerida pelos passivos socioeconômicos nacionais. Pior: ensejar-se-ia a manutenção do caráter retrógrado e subordinado, a interesses forâneos, dos arranjos estruturais de poder que vêm presidindo os destinos do Brasil.

De qualquer maneira, embora a análise desvele um quadro alarmante, viu-se, nas seções precedentes, que o referencial empírico empregado por Wilson Cano, aliado aos traços distintivos das investigações que ele empreendeu, é de grande valia para a compreensão das interdependências multiescalares que perpassam o território brasileiro na contemporaneidade. Monitorá-las e atualizá- 
las é um exercício que facilita a conversão de estudos em agendas públicas orientadas ao verdadeiro sentido do desenvolvimento, o que representa, por certo, uma deferência à memória do Mestre.

\section{Referências bibliográficas}

AFFONSO, R. B. A.; SILVA, P. B. (Org.). Federalismo no Brasil: desigualdades regionais e desenvolvimento. São Paulo: Fundap-Unesp, 1995. 2v.

AlMEIDA, J. C.; BELlUZZO, L. G. M. Depois da queda. São Paulo: Civilização Brasileira, 2002.

ARAÚJO, T. B. La division interegionale du travail au Brésil et l'exemple du Nord-Est. Paris: Université de Paris, 1979.

ARAÚJO, T. B. Industrialização do Nordeste: intenções e resultados. In: SEMINÁRIO INTERNACIONAL SOBRE DISPARIDADE REGIONAL. p. 292-301. Anais... Recife, Fórum Nordeste/Sudene, 1982.

ARAÚJO, T. B. Ensaios sobre o desenvolvimento brasileiro - Heranças e urgências. s.l.: Ed. Revan, 2000.

BACHA, E.; BONELLI, R. Uma interpretação das causas da desaceleração econômica do Brasil. Revista de Economia Política, v. 25, n. 3 (99), p. 163-189, jul./set. 2005.

BIELSCHOWSKY, R. Palestra proferida no IE-Unicamp. Campinas: IE/Unicamp, Rede D, abr. 2012.

BNB. Nordeste 2022: estudos prospectivos (documento-síntese). Fortaleza: Banco do Nordeste do Brasil, 2014.

BRAGA, J. C. S. A financeirização da riqueza: a macroestrutura financeira e a nova dinâmica dos capitalismos centrais. Economia e Sociedade, Campinas, Unicamp/IE, n. 21, 1993.

BRANDÃO, C. A. Território e desenvolvimento: as múltiplas escalas entre o local e o global. Campinas, SP: Editora da Unicamp, 2007.

BRANDÃO, C. A.; OLIVEIRA, F. L. P.; GUIMARÃES NETO, L.; SANTOS, V. M. Wilson Cano, intérprete da questão regional e urbana do Brasil. Revista Brasileira de Estudos Urbanos e Regionais, v. 22, jan./dez. 2020.

BRENNER, N.; PECK, J.; THEODORE, N. Após a neoliberalização. Cad. Metrop., São Paulo, v. 14, n. 27, p. 15-39, jan./jun. 2012.

CANO, W. Raízes da concentração industrial em São Paulo. Tese (Doutorado)-IE/Unicamp, Campinas, 1975. 335p.

CANO, W. Soberania e política econômica na América Latina. São Paulo: Ed. Unesp, 2000.

CANO, W. Ensaios sobre a formação econômica regional do Brasil. Campinas, SP: Editora da Unicamp, 2002.

CANO, W. Desequilíbrios regionais e concentração industrial no Brasil: 1930-1970. São Paulo: Editora Unesp, 2007. 
CANO, W. Desconcentração produtiva regional do Brasil (1970-2005). São Paulo: Editora Unesp, 2008.

CANO, W. Ensaios sobre a crise urbana no Brasil. Campinas, SP: Editora da Unicamp, 2011a.

CANO, W. Novas determinações sobre as questões regional e urbana após 1980. Revista Brasileira de Estudos Urbanos e Regionais, v. 13, n. 2, $2011 \mathrm{~b}$.

CANO, W. A desindustrialização no Brasil. Campinas, SP: IE-Unicamp, jan. 2014. Mimeo.

CANO, W. Introdução. In: MONTEIRO NETO, Aristides; CASTRO, César Nunes de; BRANDÃO, Carlos Antônio (Org.). Desenvolvimento regional no Brasil: políticas, estratégias e perspectivas. Brasília, DF: Ipea, 2017.

CARDOZO, S. Guerra fiscal no Brasil e alterações das estruturas produtivas estaduais desde os anos 1990. Tese (Doutorado)-IE-Unicamp, Campinas, 2010. 330p.

CARNEIRO, R. Desenvolvimento em crise: a economia brasileira no último quarto do século XX. São Paulo: Editora da Unesp, 2002.

CARVALHO, J. O. Desenvolvimento regional: um problema político. Campina Grande: EDUEPB, 2014.

CICF. Wilson Cano. Cadernos do Desenvolvimento, Rio de Janeiro, Centro Internacional Celso Furtado, v. 8, n. 13, p. 292-308, jul./dez. 2013.

DINIZ, C. C. Repensando a questão regional brasileira: tendências, desafios e caminhos. Painel "Distribuição de Renda - Redução das Disparidades Regionais". Rio de Janeiro: BNDES, set. 2002.

DUNHAM, D. Intereses de grupo y estructuras espaciales. Algunas propuestas teóricas. Documento CPRD-C/40, Santiago de Chile: ILPES, 1976.

FAVARETO, A. S. (Org.). Entre chapadas e baixões do Matopiba: dinâmicas territoriais e impactos socioeconômicos na fronteira da expansão agropecuária no cerrado. São Paulo: Prefixo Editorial, 2019.

FIORI, J. L. As trajetórias intelectuais do debate sobre desenvolvimento na América Latina. In: BRANDÃO, C. A. (Org.). Teorias e políticas do desenvolvimento latino-americano. Rio de Janeiro: Contraponto, 2018. p. 17-46.

FRIEDMANN, J. A generalized theory of polarization. Santiago de Chile: Ford Foundation, 1967.

FURTADO, C. Formação econômica do Brasil. São Paulo: Nacional, 1977.

FURTADO, C. Os desafios da nova geração. Jornal dos Economistas, jun. 2004.

GALVÃO, O. J. A. Comércio inter-regional e internacional e a economia de Pernambuco. In: GOMES, G. M. (Coord.). A economia de Pernambuco: uma contribuição para o futuro. Recife: Governo do Estado de Pernambuco, Secretaria de Planejamento, 2005.

GALVÃO, A. C.; BRANDÃO, C. A. Fundamentos, motivações e limitações da proposta governamental dos "Eixos" Nacionais de Integração e Desenvolvimento. In: GONÇALVES, Maria 
Flora; BRANDÃO, Carlos Antônio; GALVÃO, Antônio Carlos (Org.). Regiões e cidades, cidades nas regiões: o desafio urbano-regional. São Paulo: Unesp/Anpur, 2003.

GEREFFI, G. The governance of global value chains. Review of International Political Economy, v. 12, n. 1, p. 78-104, Feb. 2005.

GUIMARÃES NETO, L. Desafios para uma política nacional de desenvolvimento regional. Entrevista especial. Rev. Políticas Públicas, São Luís MA, v.16, n.1, jan./jun. 2012.

GUIMARÃES NETO, L. Trajetória econômica de uma região periférica. Estudos Avançados, São Paulo, v. 11, n. 29, jan./abr. 1997.

GUIMARÃES NETO, L. Introdução à formação econômica do Nordeste. Recife: Massangana - FJN, 1989.

GUIMARÃES NETO, L.; OLIVEIRA, F. L. P. A dinâmica da economia e transformações relevantes. In: ARAÚJO, T. B. (Org.). Socioeconomia pernambucana: mudanças e desafios. Recife: CEPE, 2018. p. 17-45.

GUIMARÃES, P. F. et al. Atuação do BNDES na região Nordeste. In: GUIMARÃES, P. F. et al. (Org.). Um olhar territorial para o desenvolvimento: Nordeste. Rio de Janeiro: Banco Nacional de Desenvolvimento Econômico e Social, 2014. p. 50-66.

IEDI - Instituto de Estudos para o Desenvolvimento Industrial. Mudança estrutural e produtividade industrial. São Paulo: IEDI, nov. 2007.

KON, A. (Org.). Unidade e fragmentação: a questão regional no Brasil. São Paulo: Ed. Perspectiva, 2002.

MARANHÃO, C.; ROMÃO, E. A nova economia de Pernambuco: análise econômico-fiscal dos setores industrial, atacadista e varejista. Recife: CEPE, 2014.

MELLO, E. C. Rubro Veio: o imaginário da restauração pernambucana. Rio de Janeiro: Topbooks, 1997.

MONTEIRO NETO, A. Desenvolvimento regional em crise: políticas econômicas liberais e restrições à intervenção estatal no Brasil dos anos 90. Tese (Doutorado)-Unicamp. Instituto de Economia, Campinas, SP, 2005. 299p.

MONTEIRO NETO, A. Intervenção estatal e desigualdades regionais no Brasil: contribuições ao debate contemporâneo. In: CARVALHO, A.; ALBUQUERQUE, C.; MOTA, J.; PIANCASTELLI (Org.). Ensaios de Economia Regional e Urbana. Brasília: Ipea, 2008. p. 375-436.

MACEDO, F. C.; PORTO, L. R. Proposta de atualização das tipologias da PNDR: nota metodológica e mapas de referência. Ipea, 2018. p. 1-67. (Texto para Discussão, n. 2414).

OLIVEIRA, F. Elegia para uma Re(li)gião/Noiva da revolução. São Paulo: Boitempo, 2008.

OLIVEIRA, F.; REICHSTUL, H. P. Mudanças na divisão interregional do trabalho no Brasil. Estudos Cebrap, v. 4, p. 131-168, 1973. 
OLIVEIRA, F. L. P. Desenvolvimento capitalista e trajetórias empresariais em Pernambuco. Tese (Doutorado)-IE/Unicamp, Campinas, 2014. 357p.

OLIVEIRA, F. L. P.; WERNER, D. Perspectiva histórica do planejamento regional no Brasil. Santiago: Cepal, 2013

PACHECO, C. A. Fragmentação da Nação. Campinas: IE/Unicamp, 1998.

PAUlA, J. A. Desenvolvimento: tentativa de conceptualização. Revista Eletrônica Gestão \& Sociedade, v. 10, n. 27, p. 1523-1539, set./dez. 2016.

PERRUCI, G. A formação histórica do Nordeste e a questão regional. In: MARANHÃO, S. (Org.). A questão Nordeste. Estudos sobre formação histórica desenvolvimento e processos políticos ideológicos. Rio de Janeiro: Paz e Terra, 1984. p. 11-30.

PINTO, A. Naturaleza e implicaciones de la "heterogeneidad estructural" de la América Latina. El Trimestre Económico, México, DF, v. 37, n. 1 (145), jan./mar. 1970.

RODRÍGUEZ, O. El estructuralismo latino-americano. Ciudad de México: Siglo XXI/Comisión Económica para América Latina y el Caribe, 2006.

VASCONCELOS, J. R. Análise da matriz por atividade econômica do comercio interestadual no Brasil. Brasília: Ipea, 2006. (Texto para Discussão, n. 1159).

SAMPAIO, D. P. Desindustrialização e estruturas produtivas regionais no Brasil. Tese (Doutorado)-IE/Unicamp, Campinas, SP, 2015. 234p.

SANTOS, A. M. S. P. Política urbana no contexto federativo brasileiro: aspectos institucionais e financeiros. Rio de Janeiro: UERJ, 2017.

SARTI, F. HIRATUKA, C. Desenvolvimento industrial no Brasil: oportunidades e desafios futuros. Campinas, SP: Unicamp. Instituto de Economia, 2011. (Texto para Discussão, n. 187).

SMITH, N. Desenvolvimento desigual. Rio de Janeiro: Bertrand Brasil, 1988.

TAVARES, M. C. Ciclo e crise: o movimento recente da economia brasileira. Campinas: Ed. da Unicamp, 1998.

TAVARES, M. C. Império, território e dinheiro. In: FIORI, J. L. Estados e moedas no desenvolvimento das nações. Petrópolis: Ed. Vozes, 1999.

VIEIRA, D. J. Um estudo sobre a guerra fiscal no Brasil. Tese (Doutorado)-Unicamp. IE, 2012. Campinas, SP, 2012. 216p.

VILAÇA, M. V.; ALBUQUERQUE, R. C. Coronel, coronéis. Brasília, DF; Editora da UnB / Rio de Janeiro, RJ: Tempo Brasileiro, 1978.

WERNER, D. Fases de neoliberalización, provisión de infraestructura y el "efecto China" en Brasil después de los años noventa. Revista EURE - Revista De Estudios Urbano Regionales, v. 46, n. 139, 2020. 